\title{
Social Campaign of Sekolah Pemuda Desa (Young Villagers School) by Ketjilbergerak Community in Efforts to Develop Villages
}

\author{
Anasvita Fardiawan ${ }^{1}$, Chatia Hastasari ${ }^{2}$ \\ ${ }^{1,2}$ Department of Communication Science, State University of Yogyakarta, Indonesia \\ ${ }^{1}$ anasvita.athaya2016@student.uny.ac.id, ${ }^{2}$ chatia@uny.ac.id
}

\begin{abstract}
This research explained the implementation of Sekolah Pemuda Desa (Young Villagers School) social campaign comprising some phases, i.e. problem identification; campaign organization by deciding the communicator, the message, the media, and the target; and the resulted effects. This study used qualitative methods by collecting data in form of ih-depth interviews and document studies. The existing intercultural communications adhering to the young villagers from interaction in Javanese language eased the social campaign to be accepted by the young villagers. This social campaign was also supported by the tight relationship from interpersonal communication between one young villager to another, so that it created an effective collaborative communication between them and Ketjilbergerak community. The problem solving that was done was evaluating the message context delivered during the social campaign. Further, the supporting factors of this social campaign were the active target, segmented messages, the existence of public support and communication in a network, as well as realistic purposes. The obstacle factors were sociologist, anthropologist, semantic, and mechanical.
\end{abstract}

Keywords: Social campaign, Community, Social Change, Young Villagers

\section{Introduction}

In order to uphold the citizens' priority needs to increase the prosperity and the distribution of village development, therefore, in 2019, the Regional Government allocated village fund as many as 933,9 million per village in Special Region of Yogyakarta. This number had been increasing from 2015 until 2018 that was about 280 million into 800, 5 million for each village. This amount was aimed to increase public services in village, alleviate poverty, advance the village's economy, resolve the development gap between villages, and strengthen the human resource as the subject of development [1]

However, in reality, the current situation shows that the villagers have not yet fully understood on how the implementation of this village fund allocated by the government. Up to this day, villagers still become the object of development. This is in line with the opinion of a Village Secretary in Bangka Belitung province saying that the village government and the villagers need to be encouraged so that they can be creative and innovative. The villagers and citizens shall not be placed as the development object, yet as the development subject. They need to be involved in each development phase, i.e. planning, conducting, up to the follow-up stage [2].

To make the citizens can take the role as the development subject; therefore, human resource improvement is needed. For this aim, human resource in village shall be built from 
the youths. One of the regencies in Indonesia that possessed quite many youth population is Yogyakarta, that is 2.490 .316 million in 2018 that increased up to 2.503 .202 million in 2019 [3].

This high number of youth in Yogyakarta then underlay the emergence of Ketjilbergerak, a social community in Yogyakarta focusing on social conditions with youth as its base. Ketjilbergerak is a youth based community engaging on the work field of education in cultural area by art and creative methods done collaboratively and independent. This collaborative action resulted synergy among Ketjilbergerak Community, Corruption Eradication Commission, and Village Ministry wherein in 2017 gave birth to the emerge of Sekolah Pemuda Desa social campaign whose vision and mission are to make the youths can develop their villages through utilization and supervision on the village fund for their villages' development.

The aim of conducting this program was to campaign the youth spirit in villages to prevent corruption. Young villagers are expected to understand the ins and outs of the village fund. They are also encouraged to participate on the planning, budgeting, using, organizing, and supervising the village fund as well as being able to map the village potential in efforts of their village development. It is also hoped that this program can have efficient impacts for the youths in their contribution towards the village development and the wide involvement of youth's role.

The main qualification of success in a village development program is by involving villagers' participations. It is an involvement or participation in which if it is being related to the village development, it is the villagers' participations, specifically youth villagers. In this case, the youth's spirit is demanded to be able to participate in developing their villages. However, there are still many youths who are unwilling to be involved in this kind of development for some reasons. This is marked by the high number of young people who go for wandering off, who are less confident to show their own potentials and who decided to have early age marriages that resulted to the low participation in the young villagers program [4]. Young people have big role towards the national development, specifically village development. In this case, the youth potential is quite high to be able to participate on the village development because youths are also the agent of change for the village that are worth to consider. From the above explanation, this research will study deeper on the social campaign by Ketjilbergerak Community as an effort in developing villages.

\section{Method}

According to Moleong, descriptive research is a research aimed to describe an event happening at this time. Its purpose is to explain a phenomenon concerning on the writing procedure that results to the written descriptive data from the research object [5].

The data source of this research was interview results towards Ketjilbergerak Community founder and youth representatives of Sekolah Pemuda Desa year 2017 - 2019. Secondary data are data that cannot be directly obtained, for example documents or information from people other than the informan. The secondary data in this research were documents of Ketjilbergerak Community event reports, meeting notes, and event posters that supported the primary data. 


\section{Results And Discussions}

\subsection{Result}

Sekolah Pemuda Desa social campaign by Ketjilbergerak community was done in some phases, from the planning stage up to the evaluation, so that it can contribute to the effort of developing villages. This is in line with the definition of campaign which is as a set of wellplaned communication behaviours aimed to create certain effect on the big mass done continuously in a certain range of time [6].

The following is a set of communication behaviours done by Ketjilbergerak community in regard to the implementation of Sekolah Pemuda Desa social campaign by using Ostegaard's campaign model. The first stage was problem identification. This was done through a contextual discussion forum with an agenda of reading the problems by the young villagers due to their knowledge about the socio-cultural environment in their own villages. Other than that, problem identification was also done together with other parties such as Corruption Eradication Commission, and the Village Ministry.

After identifying the problems, the next phase was organizing the campaign through doing research based on the problems and the technical implementation of Sekolah Pemuda Desa program. Further, deciding the actor as the communicator in delivering the massages during Sekolah Pemuda Desa social campaign was also done. As for the social campaign communicator at that time were the Village Ministry, Corruption Eradication Commission, and the manager of Ketjilbergerak community. Other communicators were the alumni of Sekolah Pemuda Desa and external speakers who is changed annually.

The next phase was deciding the message that will be brought into the social campaign. The messages were in the form of materials about village, youth, and village branding. After deciding the message, the next step is deciding the public target, which were 17 until 30 years old young villagers. Afterwards, deciding the message delivery channels that were done through offline and online. The offline campaign was conducted by socialization and workshop to train the youth's ability through direct practice. Meanwhile, the online campaign was done by utilizing social media through promoting this social campaign in Instragram and Facebook as well as holding Kuis Desa (Village Quiz) containing questions on the knowledge about the village which wrapped in Javanese to make it became closer to the young villagers.

The last phase was the resulted effect. The effect of this social campaign was the increase of youth villagers' knowledge on efforts of developing villages. Another effect was the rise of youth's spirit to be more brave and confident to make communication with other youth community through a network group of Sekolah Pemuda Desa alumni. By these, the relations owned by the youth villagers can be wider. On the stage of problem solving, what was done was evaluation through non-formal meetings that usually have no exact, certain themes to discuss. An issue that may appear was about the message context that will be conveyed, whether it has met the youth's problem in village and the media used for the social campaign. However, when the meeting was conducted online, there were some problems related to the signal to connect to the online platform and the low presence in that platform hindering the process of problem solving at evaluation stage.

\subsection{Discussion}

In Sekolah Pemuda Desa social campaign, intercultural communication which involves participants who represent personal, interpersonal, or group with pressure on the cultural 
background differences affects the participants' communication behaviours. By this cultural background difference between the communicator and the communicant, the Javanese communication can affect the communicant's behaviour, makes the campaign can be easily accepted [7].

Lalita argues that the campaign message delivered in Bahasa Indonesia, and specifically added by regional technical terms wherein the public target live in can be more persuasive [8]. The case was the same with Kuis Desa (Village Quiz) as one of social campaign output wrapped in Javanese to make it closer to the mass who are young villagers in Central Java and its surroundings.

This tight communication between one young villager to the others was made by interpersonal communication between them so that it can give them overtness in their own selves raising positive impact. Interpersonal communication is face to face communication, person to person interaction, two-way, verbal and non-verbal, as well as sharing information and feelings between individuals or among individuals in a small group [9].

This change is in accordance to the purpose of social campaign which centred on this social change. This is also in line with Soerjono's explanation that there are eight factors influencing the process of change in society, which are contact with other cultures, an advanced formal education system, society who desires advancement, responsiveness on any change deviating the norms, heterogeneous community, dissatisfaction on certain life domain, future oriented principle, and desire to improve life [10].

In this matter, the villagers have been opened for other cultures by trying to accept them without forgetting the local wisdom existing in the villagers' society. A change can be accepted by the society only if the change brings advantages to them. The society also collaborates with the governmental institution to maximize the village potential and make the best effort to create job vacancies available in village.

The villagers have owned tolerance towards the inappropriate social change in their society. However, on the other side, there are still villagers who realize on this deviation, yet they choose to tolerate or even ignore it as they feel that there is nothing they can do. The villagers are citizens who are heterogeneous. This explains that they come from basically the same culture. Even though some of them may come from different culture, they will exactly fuse to the existed culture to keep the local wisdom. Some villagers may have dissatisfaction towards certain life domain, yet they accept it and realize of what they have been endeavoured and the processes they have been passed. In this case, the youth has to have innovation in actualizing this work.

The above explanation shows that the social change in society has purposes that agree with what is explained by Johnson in Nurhadi that social change and culture are mainly based on the change happening at the process of production. This kind of change can cover new technology development, the discoveries of new things, or any other new technology development in the field of productive activity. The productive activity that is meant is Sekolah Pemuda Desa social campaign and the programs initiated by the youth in their efforts in developing villages [11].

By this, social campaign can be said as well-conducted because it is supported by the relationship governed between the doers and their environment. One of them was done by one to another young villagers as well as Ketjilbergerak Community that was supportive to the village development. Henceforth, it is shown that the reliability of becoming a group/community really depends on the ability to adapt with the environment through communication. Bona fide group theory explains that by the dependability between community and environment, therefore, the community boundary itself is not absolute. This 
individual reliability in a group is precisely intertwined in communication involving the environment, including other groups. Any interaction and dialogue involving other groups and the environment system will show the individual's loyalty towards his/her own group [12].

Just like any other campaigns, this Sekolah Pemuda Desa social campaign also has supporting factors. The success of a campaign is marked with four things as stated by Kotler and Roberto [6]. The first is the presence of active target. In this case, Ketjilbergerak Community applied strategic approach in analysing public as the campaign target who are were youths, especially young villagers.

The second mark is segmented messages that can be adjusted to the targeted public. Message is a strategy to make the youth as the target to be able to follow the campaign process well. These messages were wrapped in accordance to the youth culture by using simple and understandable language. Moreover, the messages were selected to be fit to the problem context faced by the youth, that is related to the problems in village as well as materials about youth that are hoped can motivate them.

Third, supports also can trigger success to Sekolah Pemuda Desa social campaign. These supports were given because this social campaign can accommodate public's aspiration and ideas as there was no such place to accommodate youth's aspiration. The fourth mark was realistic goal. In deciding the goal of this social campaign, Ketjilbergerak Community held a discussion together with the young villagers, Corruption Eradication Commission, and Village Ministry to seek for the middle way on the problems, such as problems in deciding the program branding, technical implementation, and the materials that will be brought. The social campaign also will be easily success if it is supported with network communication through Silaturahmi (forum of socializing) to make the same perception and perspective. Ketjilbergerak Community is not like any other organizations, so that there is no clear benchmark as well as follow up.

From the supports that were found in the field, there were also obstacles. The obstacles that are meant were communication obstacles such as sociological obstacle coming from the differences of group, social stratification, religion, ideology, education, wealth, and so on. For this matter, the obstacle found in Ketjilbergerak Community was background difference between the communicator and the communicant. The communicants here were young villagers facing social situation where they rarely deliver their thoughts in front of public. As a result, when the space for making dialogues has been opened, they often became nervous when delivering their ideas.

The next obstacle was anthropological obstacle, that is difference on the culture, life style, norms, habits, and languages existed in society. The obstacle faced by Ketjilbergerak Community as communicator was the young villagers' habits or life style which are usually silent, rarely speak up their opinions and less-connected with other young people.

Another obstacle was semantic or language obstacle. This semantic factor is related to the language used by the communicator as a tool in conveying thoughts and feelings to the communicant. The problem experienced by the communicant in this social campaign was the language that sounds too bureaucracy, makes the youth find it difficult to understand the message. The last obstacle was mechanical obstacle that came from the technical usage of the message delivery tool. In this case was the use of online meeting platform that became an obstacle because it is influenced by geographical condition that may cause low signal which then affected the number of the participants making the messages delivery became ineffective. The communication obstacles faced by Ketjilbergerak Community in implementing Sekolah Pemuda Desa social program were in line with those proposed by Effendy. He states that 
factors hindering communication are composed of socio-anthro-psychologist, sociologist, anthropologist, psychologist, semantic, mechanic, and ecologist [13].

\section{Conclusion}

Sekolah Pemuda Desa [Young Villagers School] social campaign have passed some phases started from problem identification done all together with the young villagers and other connected parties such as Corruption Eradication Commission and Village Ministry. The next phase was organizing campaign wherein there are some message conveyers come from Ketjilbergerak Community, Village Ministry, Corruption Eradication Commission, the alumni of Sekolah Pemuda Desa, and other successful young villagers. The messages were about village fund, youth, and village branding. The social campaign channel that were used were offline (through a set of workshop and training) and online (through social media, such as Instagram and Facebook) as well as using another media, for example, by inserting the message in song lyrics. The target of Sekolah Pemuda Desa campaign was youth from villages aged 17-30 years old. The resulted effect was the increasing of youth's knowledge towards the efforts that can be done to develop their villages. By the intercultural communication adhering to the youth villagers that came up from the interaction during the campaign by using Javanese, the social campaign became easier to be accepted. The social campaign was also supported by the close relationship among the young villagers that come from the interpersonal communication, which resulted to an effective, collaborative communication. The problem solving that was done was in the form of evaluation towards the message context uttered during the social campaign. The social campaign supporting factors were the active target, the segmented messages, the supports to accommodate public's aspiration, the realistic purpose, and the campaign personnels' supports which were followed personally through network communication. The hindering factors were sociologist, anthropologist, semantic, and mechanical.

\section{References}

[1] "Pelaksanaan Dana Desa Dan Dana Kelurahan Di Diy."

[2] "Masyarakat Harus Menjadi Subjek Pembangunan." https://babelprov.go.id/content/masyarakat-harus-menjadi-subjek-pembangunan (accessed Jul. $31,2020)$.

[3] “Jumlah Penduduk Menurut Jenis Kelamin D.I. DI Yogyakarta Semester I 2014." https://kependudukan.jogjaprov.go.id/statistik.hack (accessed Jul. 31, 2020).

[4] M. Kasila and L. M. Kolopaking, "Participation of Rural Youth in Business Development of BUMDes 'Tirta Mandiri,'” J. Sains Komun. dan Pengemb. Masy. [JSKPM], vol. 2, no. 1, p. 43, Feb. 2018, doi: 10.29244/jskpm.2.1.43-58.

[5] L. Moleong, "Metode penelitian kualitatif," 2007.

[6] A. Venus, S. R. Karyanti, and J. Rakhmat, "Manajemen kampanye: panduan teoritis dan praktis dalam mengefektifkan kampanye komunikasi," 2004.

[7] A. E. Putra, "Membangun Komunikasi Sosial Antaretnik: Perspektif Sosiologi Komunikasi," Aug. 2017. doi: 10.24042/AJSLA.V12I1.1441.

[8] L. Hanief, N. Sari, and A. Sanjaya, "Kampanye Lingkungan Hidup Forum Komunitas Hijau dalam Pelestarian Alam di Kota Banjarmasin," Komunida Media Komun. dan Dakwah, vol. 09, pp. 53-65, 2019, Accessed: Jul. 31, 2020. [Online]. Available: 
http://ejurnal.stainparepare.ac.id/index.php/komunida.

[9] S. Aw, "Komunikasi interpersonal," 2011.

[10] S. Soekanto and S. Soemarjan, "Sosiologi: suatu pengantar," 1969.

[11] N. Nurhadi, "Penyebab Perubahan Komunitas Sosial Beralih Ke Kafe Sebagai Pusat Aktivitas (Studi Strukturasi Anthony Giddens pada 3 Komunitas Berbasis," 2019. Accessed: Jul. 31, 2020. [Online]. Available: http://scholar.unand.ac.id/44310/.

[12] A. F.-J. I. Komunikasi and undefined 2013, "Relasi Komunikasi Kelompok," jurnalfdk.uinsby.ac.id, Accessed: Jul. 31, 2020. [Online]. Available: http://jurnalfdk.uinsby.ac.id/index.php/JIK/article/view/133/107.

[13] O. Effendy, "Dinamika komunikasi," 2008. 